\title{
Statistical optimization and valuable applications of bioactive compounds produced by marine Pseudoalteromonas piscicida
}

\author{
Sahar Wefky Mostafa Hassan ${ }^{1}$, Nermeen Ahmed El Sersy ${ }^{1}$, Abeer El-Sayed Abdelwahab ${ }^{2}$, \\ Mohamed Abdel-Rahiem Ali ${ }^{1}$ \\ ${ }^{1}$ National Institute of Oceanography and Fisheries, Microbiology Lab, Environmental Division, Alexandria, Egypt. \\ ${ }^{2}$ Medical Biotechnology Department, Genetic Engineering and Biotechnology Research Institute (GEBRI), City for Scientific Research and Technology \\ Application, Borg El-Arab, Alexandria, Egypt.
}

\section{ARTICLE INFO \\ Article history: \\ Received on: 27/09/2016 \\ Accepted on: 05/03/2017 \\ Available online: 30/10/2017}

\section{Key words:}

Pseudoalteromonas

piscicida; antibacterial, anticancer, antioxidant, Plackett Burman design; immobilization.

\begin{abstract}
Pseudoalteromonas piscicida was isolated from sea water in Suez Bay and identified using 16S rRNA sequence analysis. The bacterium produced compounds active against different pathogenic microbes including Staphylococcus aureus, Pseudomonas aeruginosa, Escherichia coli, Vibrio anguillarum, Aeromonas hydrophila and Candida albicans. Plackett Burman experimental design was applied to achieve maximum production of the bioactive compounds. It achieved 1.2 fold increase when grown in medium composed of $\mathrm{g} / \mathrm{l}$ : peptone, 3 ; beef extract, 1 ; inoculum size $(\mathrm{ml}), 0.5$; culture volume $(\mathrm{ml}), 25 \mathrm{ml}$; sea water concentration $>100 \%$ adjusted to $\mathrm{pH}$ 9 and incubation period $18 \mathrm{~h}$ at $32^{\circ} \mathrm{C}$. Immobilization using adsorption technique on different support materials was applied to improve the productivity. Cells adsorbed on medical pumice realized 1.4 fold increase than the free cells. Recycling of the immobilized cells caused an increase by 1.5 fold than the free cells. Moreover, the anticancer activity of the produced compounds were tested against 4 cell lines (EI-4, Caco-2, HepG2, MCF-7). The highest activity (63.8\%) was detected against Caco- 2 cell line while very low activity was detected towards HepG2 and EI-4 cell lines. Antiviral activity was also studied. It succeeded to inhibit HCV replication at 100 $\mu \mathrm{g} / \mathrm{ml}$. Another aim was to test the antioxidant activity. There was a significant antioxidant activity compared with ascorbic acid as control. Gas liquid chromatography mass spectroscopy was used to determine the major constituents in the benzene extract. It revealed the presence of 3 major compounds which are benzene,1pentyloctyl, Benzene, 1-butylheptyl and di-n-octyl phthalate.
\end{abstract}

\section{INTRODUCTION}

Bacterial overcoming of the tools with which humans have to fight them is continuous. Resistance develops as a result of spontaneous genetic mutations and has been attributed to many factors such as widespread use of antibiotics, lack of knowledge about proper use of antibiotics, production of large quantities of antibiotic waste from livestock rearing and an over confidence in human control over infectious diseases (Leekha et al., 2011). The emergence of resistance to antibiotics in

\footnotetext{
* Corresponding Author

Dr. Sahar Wefky Mostafa Hassan, National Institute of Oceanography and Fisheries, Microbiology Lab. Marine Environmental Division, Qayetbay, Anfoushy, Alexandria, Egypt.

E-mail: saharwefky@yahoo.com
}

microbial pathogens, such as Gram-positive methicillinresistant Staphylococcus aureus (MRSA) and vancomycinresistant $S$. aureus (VRSA), have caused a resurgence of interest in the discovery of natural products with unique scaffolds to combat new diseases and drug-resistant pathogens (Xiong et al., 2012). Natural bioactive compounds have played a significant role for discovery of new drugs over the last few decades. Some of the new chemical entities and the anticancer drugs introduced into the market can be traced back to natural products (NPs') (Newman and Cragg, 2007). The majority of microbial natural products isolated from terrestrial-borne microbes have an important role in drug discovery (Bérdy, 2005). However, the discovery and development of unique NPs' has dramatically declined over the last two decades. Recent trends in drug discovery are interested in marine microorganisms as potentially productive source of novel drugs 
which cause an increase in the number of marine NPs in clinical trials (Mikhailov et al., 2002; Waters et al., 2010; Xiong et al., 2012). Marine microbes have amazing metabolic and physiological features and are an important source of new biomolecules. Fungi, bacteria and cyanobacteria obtained from different marine sources secret several bioactive compounds with antimicrobial activity against a broad spectrum of pathogens and could be used to treat infections instead of the traditional drugs (Eduardo et al., 2015). Moreover, biologically active compounds with varying degrees of action, such as anti-bacterial, anti-cancer, anti-microtubule, as well as antifouling properties, have been isolated to date from marine sources (Bhatnagar and Kim, 2010).

Production of natural products by the marine genus Pseudoalteromonas has come to attention in the natural product in the last decade. Production of an array of compounds such as pyrolle-containing alkaloids, substituted phenolic cyclic peptides and a range of bromine substituted compounds with antimicrobial, anti-fouling, algicidal and various pharmaceutically-relevant activities have been reported ((Yu et al., 1997; Vimala, 2016). Studies have been so far limited to a relatively small subset of strains compared to the known diversity of the genus so more discoveries of novel marine natural products may remain to be made (Bowman, 2007). Production of antimicrobial agents is affected by the nutritional and environmental conditions. Statistical experimental design, such as Plackett-Burman methodology is used to eliminate the limitations of singlefactor optimization process and optimizing all the affecting parameters collectively (Urvish and Gupte, 2010).

The present study was aimed to design an optimal medium for antimicrobial agent (s) production by Pseudoalteromonas piscicida. Moreover, improvement of the production was also carried out using immobilization technique. Other applications such as anticancer, antiviral and antioxidant will be tracked using different techniques.

\section{MATERIALS AND METHODS}

\section{Bacterial isolation and growth conditions}

Bacterial isolates were isolated from sea water samples along Suez Bay, Egypt. The bacterial isolates were cultivated and purified on nutrient agar medium which contains ( $\mathrm{g} / \mathrm{l})$ : peptone, 5; yeast extract, 3; agar, 20.

\section{Pathogenic indicators}

Test bacterial pathogens used in the present study included Staphylococcus aureus ATCC 6538, Escherichia coli ATCC 8739, Pseudomonas aeruginosa ATCC 6739, Vibrio anguillarum, Aeromonas hydrophila and Candida albicans. Strains were kindly provided by National Institute of Oceanography and Fisheries, Egypt.

\section{Antimicrobial activity}

The bacterial isolates were inoculated in $250 \mathrm{ml}$ flasks containing $50 \mathrm{ml}$ of nutrient broth medium. The inoculated flasks were incubated on a rotary shaker for $1 \mathrm{~d}$. the cultures were harvested at the end of the incubation period, filtered using 0.22 $\mu \mathrm{m}$ sterilized filters. The antimicrobial effect of the bacterial supernatants was investigated using the agar diffusion method (ElMasry et al., 2002). Nutrient agar plates were seeded with the target pathogenic bacteria and wells of $10 \mathrm{~mm}$ diameter were made in the plates using a sterile cork borer. $50 \mu \mathrm{l}$ of each supernatant was transferred into each well under aseptic conditions. Plates were then incubated for $1 \mathrm{~d}$ at $30^{\circ} \mathrm{C}$. Clear inhibition zone around each well was detected as the antimicrobial activity and was linearly measured in $\mathrm{mm}$.

\section{Effect of growth medium on production of bioactive compounds by $\boldsymbol{P}$. piscicida}

Cultures of the selected bacterial strain were grown using nutrient broth $(\mathrm{g} / \mathrm{l})$ : peptone 5 , yeast extract 3 and Luria Bertani $(\mathrm{g} / \mathrm{l})$ peptone 10 , yeast extract 5 and minimal medium $(\mathrm{g} / \mathrm{l})$ : glucose, $3 ;\left(\mathrm{NH}_{4}\right)_{2} \mathrm{SO}_{4}, 1 ; \mathrm{K}_{2} \mathrm{HPO}_{4} ; 1 ; \mathrm{Mg} \mathrm{SO}_{4} .7 \mathrm{H}_{2} \mathrm{O}, 0.1 ; \mathrm{NaCl}, 5$ at $30^{\circ} \mathrm{C}$ for $24 \mathrm{hrs}$. Cell free supernatant of each culture was tested against the previously chosen target pathogens using well cut diffusion technique aiming at obtaining the highest antimicrobial activity (Aassila et al., 2003).

\section{Optimization of nutritional factors}

Optimization of the culturing conditions was investigated in order to reach to a maximum production of the antimicrobial agents. Plackett-Burman statistical design (Plackett and Burman, 1946; Yu et al., 1997) was applied to reflect the relative importance of various factors involved in the production of these agents by $P$. piscicida.

For each variable a high (+) and low (-) levels were tested. Eight different trials were performed in duplicates. Table 2 represents the high and low concentration of the different Independent variable (factors) affecting the production of antimicrobial agents. The rows in Table 3 represent the different trials (row no. 9 represents the basal control). The main effect of each variable was determined with the following equation:

$$
\mathbf{E x i}=(\mathbf{M i}+-\mathbf{M i}-) / \mathbf{N}
$$

where Exi is the variable main effect, and $\mathrm{Mi}+, \mathrm{Mi}-$ are the radius of the clear zone around each well in the trials, where the independent variable was present in high and low concentrations, respectively, and $\mathrm{N}$ is the number of trials divided by 2 . Statistical t-values for two samples assuming unequal variances were calculated using Microsoft Excel to determine the variable significance.

\section{Verification experiment}

To verify the results obtained from the statistical analysis of Plackett-Burman design, a verification tests were performed in duplicates using the predicted optimized media against the basal condition media. The production of the 
antimicrobial agents was determined by measuring the average of inhibition zones diameter ( $\mathrm{mm})$.

\section{Immobilization technique}

Immobilization was performed by adsorption of bacterial cells on different solid porous supports. $0.5 \mathrm{ml}\left(625 \times 10^{3} \mathrm{CFU} / \mathrm{ml}\right)$ bacterial suspension were added to each Erlenmeyer flasks (250 $\mathrm{ml}$ capacity) containing $25 \mathrm{ml}$ of the optimized culture medium and the porous support materials (Luffa pulp, pumice, medical pumice, ceramic, coral reefs, and sponge) were cut to small pieces, washed several times with water before use. The flasks were then shaken slowly at $120 \mathrm{rpm}$. After $18 \mathrm{~h}$ incubation, the production of bioactive compounds was estimated using the well-cut diffusion technique (Ivanova et al., 1998).

The fermentation medium containing 20 cubes of medical pumice was supplemented with $0.5 \mathrm{ml}$ of bacterial inoculum, the $\mathrm{pH}$ adjusted to 9 and incubated at $32{ }^{\circ} \mathrm{C}$ for $18 \mathrm{~h}$. The reuse of the adsorbed cells was carried out by removing the medium after $18 \mathrm{~h}$, and then a new sterilized medium $(25 \mathrm{ml})$ was added, and new cycle was run. This process was repeated several times. At the end of each cycle, the antimicrobial activity was estimated.

\section{Statistical analysis}

Data analysis was performed with the soft package

Microsoft Excel, version 2003. Statistically significant difference was determined using analysis of variance (ANOVA) and $\mathrm{p}<0.05$ was used as the limit to indicate statistical significance.

\section{Electron microscopy}

For electron microscopy, the optimized medium was inoculated with the strain and incubated for $24-48 \mathrm{~h}$. at $32^{\circ} \mathrm{C}$. Glutaraldehyde $(2.5 \%$, v/v) was used to fix the culture and postfixed in osmium tetroxide $(1 \%, \mathrm{w} / \mathrm{v})$ for $1 \mathrm{~h}$. The sample was washed twice with water and dehydrated in ascending ethanol (30 $\%, 50 \%, 70 \%, 90 \%$ and $100 \%$ ), and finally coated in gold and examined at 15-20 KV in JEOL JSM $5400 \mathrm{LV}$, scanning electron microscope, Japan at the electron microscope unit of Assuit University.

\section{Extraction of the active antimicrobial compounds}

Culture of $P$. pisicida grown under the optimized conditions was centrifuged at $8000 \mathrm{rpm}$ for $20 \mathrm{~min}$. at $4^{\circ} \mathrm{C}$. Equal volume of n-hexan, n-butanol, ethyl acetate, benzene or chloroform were used for extraction of the bioactive compounds. The organic phase was collected and evaporated using rotary evaporator, and each crude extract was dissolved in the appropriate solvent for further purification and characterization.

Each crude extract was tested for its antibacterial activity against E.coli using well cut diffusion technique. The antibacterial activity was detected as inhibition zone diameter $(\mathrm{mm})$.

\section{Thin layer chromatography}

The dissolved crude extract was chromatographed on silica gel preparative slides using different solvent systems: ethyl acetate:Hexane (1:10 and 1:20) and hexane only as mobile phases. Migration and separation of the starting crude spots using each mobile phase were observed and the retarding factor of each solute $\left(\mathrm{R}_{\mathrm{f}}\right)$ was estimated.

The active band (s) were gathered and dissolved in ethyl acetate and concentrated to dryness in the vacuum. Bioactivity of the selected bands was examined against E.coli using well-cut diffusion method. The antibacterial activity was detected as the inhibition zone diameter $(\mathrm{mm})$.

\section{Anticancer activity}

Several steps were carried out to estimate the anticancer activity: lyophilization, cytotoxicity test and effect of IC50 on three different tumor cell lines. Lyophilization included three steps. Freezing, primary drying and secondary drying. $10 \mathrm{ml}$ of filtrate were lyophilized using a Telsonlyophilizer (Spain). Different concentrations $(5,25,50,75,100 \mu \mathrm{g} / \mathrm{ml})$ of the powder were prepared and used in the second step (cytotoxicity test). The second step is the cytotoxicity test which represent a rapid sensitive and inexpensive standardized test. to determine the toxicity of the test substances. To measure cytotoxicity of the examined compounds, $5 \times 10^{4}$ lymphocyte cells were seeded per well in 96 well plates and incubated in RPMI media containing different concentrations $(5,25,50,75,100 \mu \mathrm{g} / \mathrm{ml})$ of the tested compounds and incubated for 24,48 and $72 \mathrm{hrs}$ in $5 \%$ $\mathrm{CO}_{2}$ incubator. Next, the media were removed and wells were washed with HBSS. The fraction of viable lymphocytes was measured by the MTT (3-(4,5-dimethythiazol-2-yl)-2,5diphenyltetrazolium bromide)

In this assay, the yellow MTT is reduced to purple formazan in the mitochondria of viable cells. $100 \mu \mathrm{l}$ of the MTT working solution $(0.5 \mathrm{mg} / \mathrm{ml})$ were added to each well and incubated at $37{ }^{\circ} \mathrm{C}$ for $4 \mathrm{~h}$. and media were removed, wells were washed with phosphate buffer saline, and $100 \mu$ l of dimethyl sulfoxide (DMSO) were added to solubilize the formazan crystalline product. The absorbance was measured with a plate reader at $570 \mathrm{~nm}$ and normalized to the absorbance at $630 \mathrm{~nm}$. Fraction of viable cell was determined by dividing the normalized absorbance of the test well to that of the control well (El-Hawash et al., 2006). Cytotoxicity assay was performed on different human cell line using the previously described method .

The anticancer activity of the substance was tested using different human cell lines (EI-4, Caco-2, HepG2, MCF-7). Cells (2 $\times 10^{4}$ ) were seeded per well in 96 well plates and incubated in Ham's F-12, RPMI and DMEM, respectively for $24 \mathrm{~h}$ in $5 \% \mathrm{CO}_{2}$ incubator for cell attachment. Next, the media were changed with media containing $10 \%$ of IC50 of the tested substances and cells were incubated in that media for 24,48 and $72 \mathrm{~h}$. Media without any chemical was used as the negative control. At each time point, 
the media were removed, wells were washed with $\mathrm{PO}_{4}$ buffer Saline (PB) and fractions of viable cells were measured by the MTTassay.

\section{Antiviral activity}

HepG2 cells were washed twice in RPMI1640 media supplemented with $200 \mu \mathrm{M} \mathrm{L}$-glutamine and $25 \mu \mathrm{M}$ HEPES buffer; N-[2-hydroxyethyl] piperazine-N9-[2-ethanesulphonic acid] (all chemicals and media, Cambrex). The cells were suspended at $2 \times 10^{5}$ cells/mL in RPMI culture media (RPMI) supplemented media, $10 \%$ fetal bovine serum (FBS); Gibco-BRL). The cells were left to adhere on the polystyrene 6-well plates for $24 \mathrm{~h}$ in an incubator $\left(37{ }^{\circ} \mathrm{C}, 5 \% \mathrm{CO}_{2}, 95 \%\right.$ humidity). The cells were washed twice from debris and dead cells by using RPMI supplemented media.

Cytotoxicity assay was performed on PBMC cell line using the previously described method .HepG2 cell culture were prepared as discussed before (El-Awady et al., 1996). then infected with $2 \% \mathrm{HCV}$-infected serum in RPMI culture medium containing 8\% FBS. Tested compound was added at its safe dose. Positive and negative control cultures were included. After $96 \mathrm{~h}$ of incubation at $37{ }^{\circ} \mathrm{C}, 5 \% \mathrm{CO}_{2}$, and $95 \%$ humidity a second dose of the test compound was added.

The cells were incubated for a further $96 \mathrm{~h}$ followed by total RNA extraction using the method described by ElAwady et al. (1996). The positive strand and its replicating form (negative strand) were detected by RT- PCR using HCV specific primers.

\section{Antioxidant activity}

Total phenolic content of the artichoke samples was determined using Folin-Ciocalteu assay (AOCS, 1990). A $0.5 \mathrm{ml}$ extract was added to $2.5 \mathrm{ml}$ of Folin-Ciocalteu reagent followed by addition of $2 \mathrm{ml}$ sodium carbonate $\left(\mathrm{Na}_{2} \mathrm{CO}_{3}\right)(75 \mathrm{~g} / \mathrm{l})$. The sample was then incubated for $5 \mathrm{~min}$ at $50{ }^{\circ} \mathrm{C}$. The absorbance was then measured at $760 \mathrm{~nm}$. The phenolic content was expressed as $\mathrm{mg}$ gallic acid equivalents per gram of extract ( $\mathrm{mg}$ GAE/g). The DPPH stable free radical scavenging assay was performed as previously described by $\mathrm{Hu}$ and Kitt (2000) with some modifications. Sample extract was dissolved in a methanol at different concentrations ranging from 6.25 to $100 \mu \mathrm{g} / \mathrm{ml}$ and then of the extract $(2 \mathrm{ml})$ was incubated with $0.5 \mathrm{ml}(0.2 \mathrm{mM})$ DPPH in $100 \%$ methanol. Sample absorbance at $519 \mathrm{~nm}$ was recorded after $30 \mathrm{~min}$ of incubation at room temperature. Inhibition of the DPPH stable free radical was calculated as follows:

$\%$ Inhibition $=(A B$ control $-\mathrm{AB}$ sample $) \div(\mathrm{AB}$ control $-\mathrm{AB}$

$$
\text { Blank) } \times 100
$$

Where:

Abs control $=$ absorbance of $0.1 \mathrm{mM}$ DPPH alone in methanol; Abs sample $=$ absorbance of $0.1 \mathrm{mM} \mathrm{DPPH}+$ sample extract in methanol; and Abs blank = absorbance of methanol solvent control.

\section{Spectral analysis}

Identification of constituents of the crude extract was performed using high performance 5890 gas liquid chromatography (GLC) (Hewlett Packard) coupled with 5989 B series mass spectrometer (MS) (Shimadzu (EI), Japan). The gas liquid chromatography mass spectrometer (GC-MS) peaks were identified using WILEY MASS SPECTRAL DATA BASE Library (Kaoutar et al., 2010).

\section{Characterization of the purified bioactive compounds}

IR-spectral analysis was investigated at the Faculty of Pharmacy, Alexandria University. Three milligram of the crude extract was taken and mixed well with potassium bromide $(\mathrm{KBr})$ and pressed into a disc shape. The sample was placed into the sample holder and FTIR spectra were recorded at the range 400$4000 \mathrm{~cm}^{-1}$ (Kaoutar et al., 2010). The purified bioactive compounds were characterized by recording the absorption peak using Ultraviolet-visible spectrophotometer analysis.

\section{RESULTS}

Antimicrobial resistant microorganisms cause killing of about 3 million people each year in the world (Navarri et al., 2016). This threat requires renewal of the traditional antibiotics Underexplored marine environment may represent an untapped reservoir of novel antimicrobial agents (Blunt et al., 2015).

In the present study, among 22 tested bacterial isolates coded (AB1-AB22), the marine bacterial isolate AB12 which was previously identified as Pseudoalteromonas piscicida using $16 \mathrm{Sr}$ RNA sequence analysis and has GenBank accession number of JX861209.1 exhibited broad spectrum of antimicrobial activity against the tested pathogens recording the highest antimicrobial activity $(17 \mathrm{~mm})$ against E.coli ATCC 8739. Study concerned with antimicrobial screening using nine target marine isolates against Staphylococcus aureus, Streptococcus faecalis, Pseudomonas aeruginosa, Escherichia coli, Micrococcus luteus and Candida albicans was previously carried out (Wekky et al., 2009). The antimicrobial activity of $P$. piscicida was previously proven in different studies (Bowman, 2007; Secun, 2015).

\section{Effect of growth medium type on production of the bioactive compounds}

Secondary metabolites affect by variation in the growing environment which in turn can have significant impacts on the diversity and quantity of secondary metabolites. Such optimization becomes challenging in a drug-discovery screening situation (VanderMolen et al., 2013).

Pseudoalteromonas piscicida was examined for the antagonistic activity using three different media; nutrient broth (NB), luria broth (LB) and minimal media (MM). As shown in Table 1, broad spectrum of antimicrobial activity against the tested pathogenic bacteria and also the highest inhibition zone $(19 \mathrm{~mm})$ was observed up on using nutrient broth (NB) and thus nutrient broth was used for further investigation. NB and LB were 
documented as production media for antimicrobial agents by the marine bacterium Enterococcus faecium (Wefky et al., 2009).

Table 1: Effect of different media on production of the antimicrobial agent(s) by P.piscicida.

\begin{tabular}{lccc}
\hline \multirow{1}{*}{ Pathogen } & \multicolumn{3}{c}{$\begin{array}{c}\text { Diameter of inhibition zone (mm) produced by } \\
\boldsymbol{P} \text {. piscicida } \text { using different media }\end{array}$} \\
\cline { 2 - 4 } & LB & NB & MM \\
\hline E.coli & 15 & 17 & 10 \\
V. anguillarum & 13 & 19 & - \\
A. hydrophila & - & 13 & - \\
P. aeruginosa & - & 15 & - \\
S. aureus & 13 & - & - \\
C. albicans & - & 13 & - \\
\hline
\end{tabular}

\section{Optimization of culture conditions}

Statistical experimental designs are powerful tools for rapid searching of the key factors from a multivariable system and error minimization in determining the effect of parameters and the results are achieved in an economical manner (El-Sersy, 2007; Abou-Elela et al., 2009; Shabbiri et al., 2012; Sharma et al., 2013; Saraniya and Jeevaratnam, 2014. El-Sharouny et al., 2015; Zeinab et al., 2015). The medium components in addition to some physical factors (Table 2) were examined using the design matrix (Table 3).

Table 2: Independent variables affecting production of the antimicrobial agent(s) and their levels in the Plackett- Burman design.

\begin{tabular}{cclll}
\hline Factor & \multirow{2}{*}{ Symbol } & \multicolumn{3}{c}{ Level } \\
\cline { 3 - 5 } & & \multicolumn{1}{c}{$\mathbf{- 1}$} & \multicolumn{1}{c}{$\mathbf{1}$} & $\mathbf{1}$ \\
\hline Peptone (g/l) & $\mathrm{P}$ & 3 & 5 & 7 \\
Beef extract (g/l) & $\mathrm{B}$ & 1 & 3 & 5 \\
Inoculum size (ml) & $\mathrm{IS}$ & 0.5 & 1 & 1.5 \\
Seawater concentration (\%) & $\mathrm{S} . \mathrm{W}$ & 50 & 100 & 150 \\
pH & $\mathrm{pH}$ & 5 & 7 & 9 \\
Incubation period (h). & $\mathrm{IP}$ & 18 & 24 & 48 \\
Culture volume (ml) & C.V & 25 & 50 & 75 \\
\hline
\end{tabular}

All experiments were performed in duplicates and the averages of results (diameter of inhibition zone in $\mathrm{mm}$ ) are presented as the response. Results indicated that the highest inhibition zone $(20 \mathrm{~mm})$ was against E. coli.
Table 4 and Figure 1 show the main effect of each variable on the production of the antimicrobial agents against E.coli (ATCC 8739) as well as t-values presented in Table 4. These results indicated that $\mathrm{pH}$ and sea water concentration have positive main effects while the other tested variables exhibited negative main effects on the antagonistic agents production. Statistical analyses of the results (t-test) showed that variations in sea water concentration and beef extract in the tested ranges had the most significant effects on the production of antimicrobial agents by $P$. piscicida (Table 4 ).

Table 4: Statistical analysis of the Plackett-Burman experimental design for the production of antimicrobial agents by $P$. piscicida against $E$. coli (ATCC 8739).

\begin{tabular}{lccc}
\hline Variables & Symbol & Main effect & t-value \\
\hline Peptone & $\mathrm{P}$ & -9 & 1.9 \\
Beef extract & $\mathrm{B}$ & -5.5 & $\mathbf{2 . 0}$ \\
Inoculum size & $\mathrm{IS}$ & -1 & 1.9 \\
Sea water concentration (\%) & $\mathrm{SW}$ & 2.5 & $\mathbf{2 . 0}$ \\
$\mathrm{pH}$ & $\mathrm{PH}$ & 7.5 & 1.9 \\
Culture volume & $\mathrm{CV}$ & -9 & 1.9 \\
Incubation Period & $\mathrm{IP}$ & -1 & 1.9 \\
\hline
\end{tabular}

$\mathrm{t}$-value significant at the $1 \%$ level $=3.70$.

$\mathrm{t}$-value significant at the $5 \%$ level $=2.45$.

$\mathrm{t}$-value significant at the $10 \%$ level $=1.94$.

$\mathrm{t}$-value significant at the $20 \%$ level $=1.37$.

Standard t-values are obtained from statistical methods (Cochran and Snedecor, 1989).

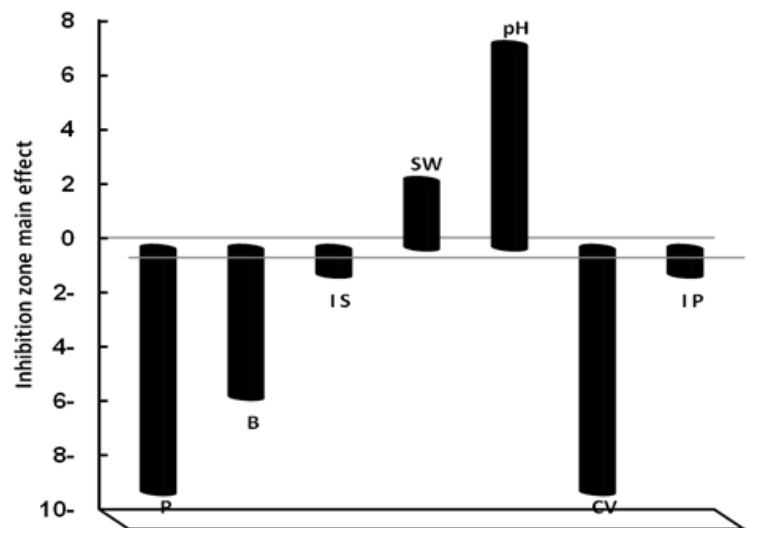

Fig. 1: Elucidation of the cultured factors that affect the production of antimicrobial agent(s) by P. piscicida against E. coli ATCC 8739.

Table 3: Experimental results of the Plackett-Burman design.

\begin{tabular}{|c|c|c|c|c|c|c|c|c|c|c|c|c|c|}
\hline \multirow[b]{2}{*}{ Trials } & \multicolumn{7}{|c|}{ Factors symbols } & \multicolumn{6}{|c|}{ (Response) Diameter of inhibition zone (mm) } \\
\hline & $\mathbf{P}$ & $\mathbf{B}$ & pH & I.S & I.P & S.W & C.V & P. aeruginosa & A. hydrophila & V. anguillarum & E. coli & C. albicans & S. aureus \\
\hline 1 & -1 & -1 & -1 & 1 & 1 & 1 & -1 & 0 & 0 & 0 & 16 & 10 & 0 \\
\hline 2 & 1 & -1 & -1 & -1 & -1 & 1 & 1 & 0 & 0 & 0 & 0 & 0 & 0 \\
\hline 3 & -1 & 1 & -1 & -1 & 1 & -1 & 1 & 0 & 0 & 0 & 0 & 0 & 0 \\
\hline 4 & 1 & 1 & -1 & 1 & -1 & -1 & -1 & 0 & 0 & 0 & 0 & 0 & 0 \\
\hline 5 & -1 & -1 & 1 & 1 & -1 & -1 & 1 & 0 & 13 & 0 & 13 & 12 & 0 \\
\hline 6 & 1 & -1 & 1 & -1 & 1 & -1 & -1 & 17 & 13 & 10 & 13 & 0 & 0 \\
\hline 7 & -1 & 1 & 1 & -1 & -1 & 1 & -1 & 0 & 14 & 0 & 20 & 0 & 15 \\
\hline 8 & 1 & 1 & 1 & 1 & 1 & 1 & 1 & 0 & 0 & 0 & 0 & 13 & 0 \\
\hline 9 & 0 & 0 & 0 & 0 & 0 & 0 & 0 & 15 & 13 & 19 & 17 & 13 & 0 \\
\hline
\end{tabular}




\section{Verification experiment}

In order to evaluate the accuracy of the applied PlackettBurman statistical design, a verification experiment was applied to compare between the predicted optimum levels of independent variables and the basal condition settings. Results in Table 5 showed that growth of $P$. piscicida on the optimized medium with the following composition: (g/l) peptone, 3; beef extract, 1; inoculum size $(\mathrm{ml}), 0.5$; culture volume $(\mathrm{ml}), 25$; sea water concentration $150 \%$ adjusted to $\mathrm{pH} 9$ and incubation period $18 \mathrm{~h}$. at $32^{\circ} \mathrm{C}$ increased the production of the antagonistic agents (expressed in $\mathrm{mm}$ diameter of inhibition zone) to $21 \mathrm{~mm}$ with 1.2 fold increase when compared to cells grown under the basal conditions.

Abd-Elnaby et al. (2016) reported that increasing levels of $\mathrm{pH}$, inoculum size caused an increase in the antagonistic activity by about 1.3 fold for Streptomyces parvus. Wefky et al. (2009) stated that peptone, beef extract, sea water concentration and culture volume were negatively affected the antagonistic activity by Enterococcus faecium. The data were also examined and compared to anti-optimized medium (Table 5).

Table 5: A verification of the Plackett-Burman experimental results that carried out using $P$. piscicida against E.coli (ATCC 8739).

\begin{tabular}{lccc}
\hline \multicolumn{1}{c}{ Response } & $\begin{array}{c}\text { Basal } \\
\text { medium }\end{array}$ & $\begin{array}{c}\text { Optimized } \\
\text { medium }\end{array}$ & $\begin{array}{c}\text { Anti-optimized } \\
\text { medium }\end{array}$ \\
\hline $\begin{array}{l}\text { Diameter of inhibition zone } \\
(\mathrm{mm})\end{array}$ & 17 & 21 & 0 \\
\hline
\end{tabular}

\section{Cell immobilization}

The majority of bacteria in the aquatic systems are organized in biofilms. This structure provides the bacteria present in biofilms with several advantages compared to the free cells (Donlan and Costerton, 2002). Immobilized cells in the production of metabolites by microbial cultures is one of the most interesting techniques proposed for development of fermentation process. Immobilized cell particles are about 1,000 times larger than free cells so they can easily be handled and packed in fermentation system for industrial processes (Darah et al., 2011). Living cells of P.piscicida were subjected to immobilization using adsorption technique with luffa pulp, ceramic, coral reefs, pumice, medical pumice and sponge as supporting materials. Results in Table 6 showed that the antimicrobial activity of immobilized $P$. piscicida on medical pumice (Figure 2) was superior than free cells and raised the activity to $23 \mathrm{~mm}$ which realized 1.4 fold increase followed by immobilized cells on pumice, coral reefs ceramic with inhibition zone diameter of 22, 21 and $20 \mathrm{~mm}$ respectively. On the other hand, the lowest antimicrobial activity was detected up on using immobilized cells on luffa pulp which reduced the antimicrobial activity by 0.94 folds. This result could be attributed to poor mechanical stability of the support (Lunestad and GoksQy, 1990). The second factor is the individual characteristics of the bacterium (Pursel et al., 1995). The present results coincide with Wefky et al. (2009) who stated that biofilm of Enterococcus faecium on pumice raised the antimicrobial activity with 1.2 fold while luffa pulp exhibited the lowest antimicrobial activity. Abd-
Elnaby et al. (2016) also reported the potentiality of the immobilized cells in raising the antimicrobial activity of Streptomyces parvus compared to free cells. The same feature was reported by Ivanova et al. (2000-2002).
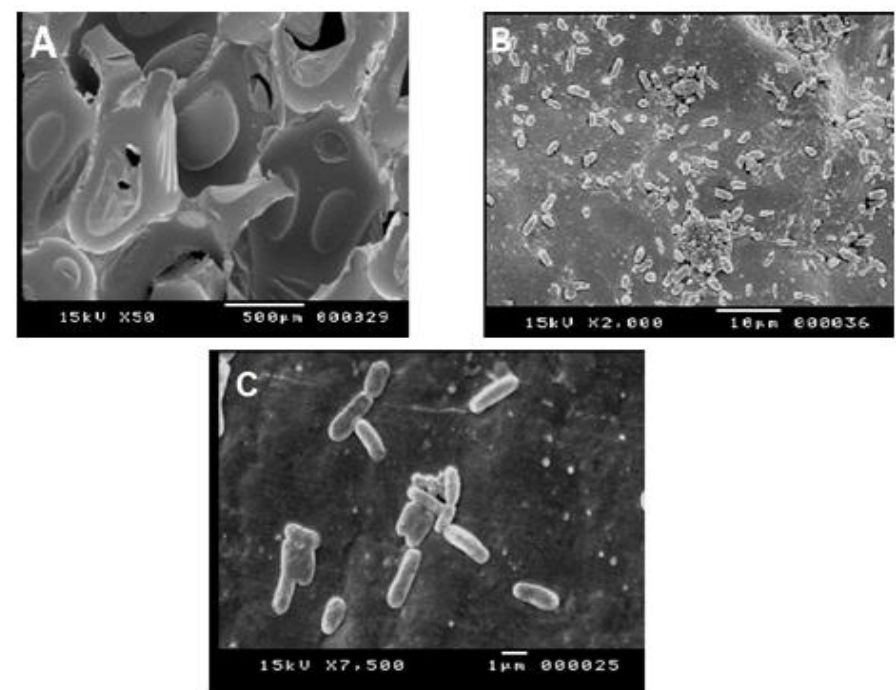

Fig 2: Scanning electron micrographs showing (A) control medical pumice; (B) P. piscicida (AB12) adsorbed on medical pumice and (C) free cells of $P$. piscicida

Table 6: Effect of immobilization on production of the antimicrobial agents by P. piscicida.

\begin{tabular}{|c|c|c|c|c|c|c|c|}
\hline \multirow[b]{2}{*}{ Response } & \multicolumn{7}{|c|}{ Antagonistic activity using different support materials } \\
\hline & 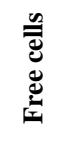 & 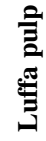 & Uֶّ & 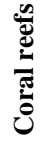 & & 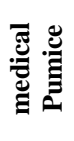 & क्ष \\
\hline IZ. & 17 & 16 & 20 & 21 & 22 & 23 & 15 \\
\hline
\end{tabular}

IZ. = Inhibition Zone (mm).

Moreover, the cells on medical pumice was recycled for four successive cycles aiming for enhancing the antimicrobial agent(s) production. As shown in Table 7 the antagonistic activity increased during $1^{\text {st }}, 2^{\text {nd }}, 3^{\text {rd }}$ and $4^{\text {th }}$ cycles compared to free cells to reach $(24 \pm 2.33,24 \pm 2.61,25 \pm 2.71,24 \pm 2.31 \mathrm{~mm}$.), respectively with significant difference (ANOVA, $\mathrm{p}<0.05$ ) compared to the free cells $(17 \pm 1.52)$ and there was 1.5 fold increase in the antagonistic activity during the third cycle.

Table 7: Immobilization cycles of antimicrobial agent(s) production on medical pumice.

\begin{tabular}{cc}
\hline Immobilization cycle & Inhibition zone $(\mathbf{m m})$ against E.coli \\
\hline $1^{\text {st }}$ cycle & $24 \pm 2.33 \mathrm{~b}$ \\
$2^{\text {nd }}$ cycle & $24 \pm 2.61 \mathrm{~b}$ \\
$3^{\text {rd }}$ cycle & $25 \pm 2.71 \mathrm{~b}$ \\
$4^{\text {th }}$ cycle & $24 \pm 2.31 \mathrm{~b}$ \\
Free cells & $17 \pm 1.52 \mathrm{a}$ \\
\hline
\end{tabular}

\section{Antibacterial activity of the extracted compounds}

The crude extracts of P.piscicida produced up on using benzene, chloroform and ethyl acetate were tested for their 
antibacterial activity against E.coli. Results in Figure 3 revealed that benzene extract recorded the highest antibacterial activity (25 $\mathrm{mm}$ ) while the lowest antibacterial activity $(22 \mathrm{~mm})$ was detected upon using ethyl acetate extract which prove the efficiency of benzene for extraction of the bioactive metabolites. Pseudoalteromonas strains are known as prolific producers of bioactive secondary metabolites with antimicrobial activity (Vynne and Gram, 2011). Marine bacteria of the genus Pseudoalteromonas are recognized as major producers of various biologically active metabolites such as halogenated compounds, cyclic compounds, enzymes (Secun et al., 2015). Kim et al. (2016) reported the production of various secondary metabolites from the genus Pseudoalteromonas against E.coli.

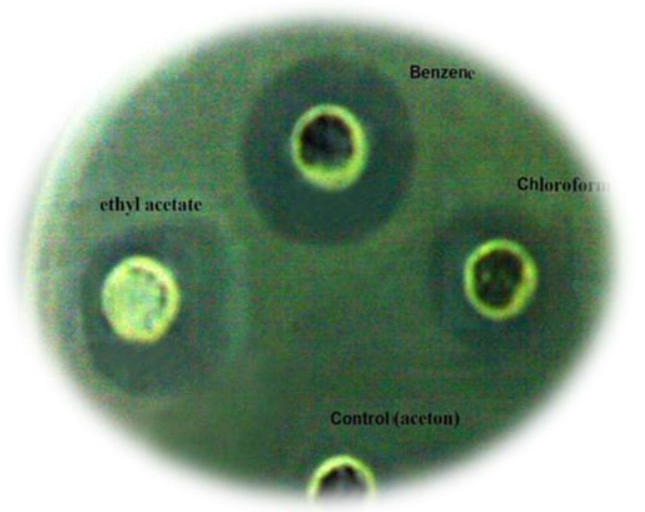

Fig. 3: Effect of solvents extracts on antibacterial activity against E.coli ATCC 8739 .

\section{Thin layer chromatography}

Partial purification of the crude extract using TLC showed 3 separated spots with $\mathrm{R}_{\mathrm{f}}$ values $0.1,0.3$ and 0.8 and they were visible under UV lamp. The antimicrobial activity of the separated spots were investigated against E. coli. As shown in Table 8

Table 8: The bioactivity of the three major components compared to the crude extract using E.coli ATCC 8739.

\begin{tabular}{cc}
\hline Crude extract \& TLC spots & Inhibition zone diameter (mm) \\
\cline { 2 - 2 } & against E.coli \\
\hline Crude extract & 25 \\
Band 1 & 11 \\
Band 2 & 15 \\
Band 3 & 9 \\
\hline
\end{tabular}

\section{Anticancer activity}

Data in Table 9 showed the effect of culture supernatant concentration on (EI-4) cell line (Figure 4A, B) using the MTT assay which causing $38 \%$ inhibition after $72 \mathrm{~h}$. Upon using tumour cell line (Caco-2) (Figure $4 \mathrm{C}, \mathrm{D})$, the supernatant of tested compound showed a reasonable degree almost $63.8 \%$ inhibition respectively after $72 \mathrm{~h}$ using the MTT assay. On the other hand, using the supernatants of the tested compound showed very low activity towards EI4 (Figure 4 A,B), (HepG2) (Figure 4 E,F) cell line and (MCF-7) (Figure $4 \mathrm{G}, \mathrm{H}$ ) as detected by MTT assays where they showed only $33 \%$ and $44.6 \%$ inhibition respectively after 72 h. Noble et al. (2016) reported that secondary metabolites from the marine Pseudoalteromonas sp. inhibited the proliferation of A549 lung carcinoma cells. Wang et al. (2012) stated that the extracted compounds from Pseudoalteromonas sp. 1020R, isolated from the Pacific coast of Japan exhibited different extents of cytotoxicity against U937 leukemia cells. In similar study, Zheng et al. (2006) reported the cytotoxicity of secondary metabolites from $P$. piscicida towards both the HeLa cervical-cancer cell line and the BGC-823 stomach-cancer cell line, with an $\mathrm{IC}_{50}$ of $5 \mu \mathrm{g} / \mathrm{ml}$

Table 9: IC50 and the percentage of inhibition of different cell line growth using the MTT assay.

\begin{tabular}{cccc}
\hline Cell line & IC50 & Inhibition \% & Time (h) \\
\hline EI-4 & 40.55 & 38 & 72 \\
Caco-2 & 54.38 & 63.8 & 72 \\
HepG2 & 70.83 & 33 & 72 \\
MCF-7 & 64.22 & 44.6 & 72 \\
\hline
\end{tabular}

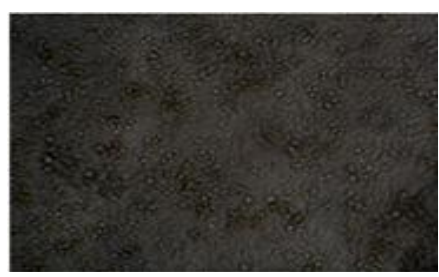

A

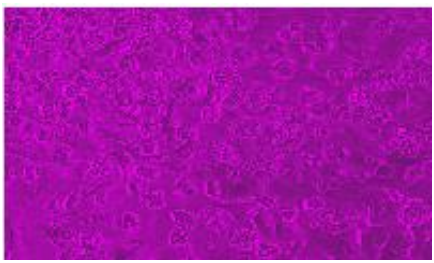

C

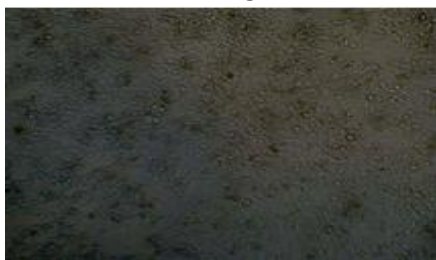

$\mathbf{E}$

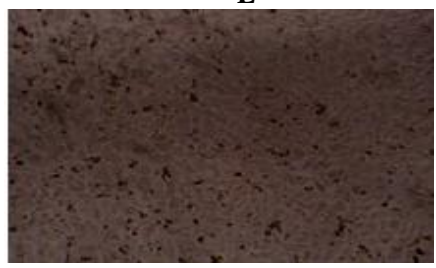

G
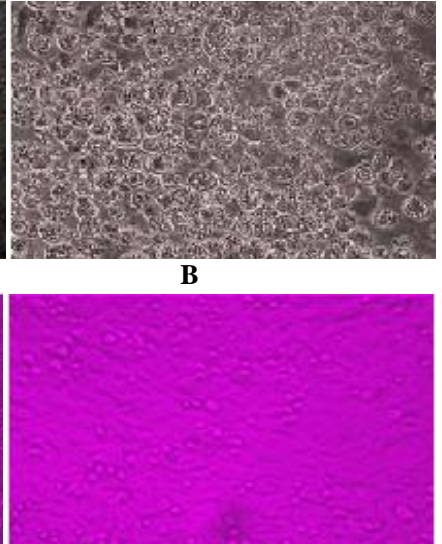

D
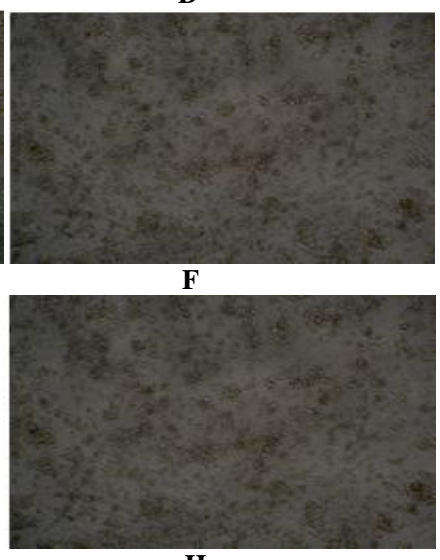

H
Fig. 4: Photographs illustrating the difference between the tested compound (B) on the growth inhibition of EI-4 tumor cell line compared to control (A), difference between the tested compound (D) on the growth inhibition of $\mathrm{CaCo}$ 2 tumor cell line compared to control (C), difference between the tested compound (F) on the growth inhibition of HepG2 tumor cell line compared to control $(\mathrm{E})$, difference between the tested compound $(\mathrm{H})$ on the growth inhibition of MCF-7 tumor cell line compared to control (G).

\section{Antiviral activity}

The supernatant of the bacterial strain $P$. piscicida succeeded to inhibit $\mathrm{HCV}$ replication at $100 \mu \mathrm{g} / \mathrm{ml}$ as shown in Figure 5. Zhou et al. (2016) found that the secondary metabolites 
produced by Pseudoalteromonas sp. exhibited antiviral activity on Bombyx mori nucleopolyhedro virus (BmNPV)-infected cells in vitro, with specific modes of action and selectively killed virusinfected cells, inhibited viral gene transcription. In another study, Elnahas et al. (2011) reported the antiviral activity of secondary metabolites produced by Pseudoalteromonas sp. against herpes simplex (HSV-I) activities. In that context, the antiviral activity of sulfated EPSs was attributed to their ability to inhibit virus particle adsorption to host cells (Llamas et al., 2010).

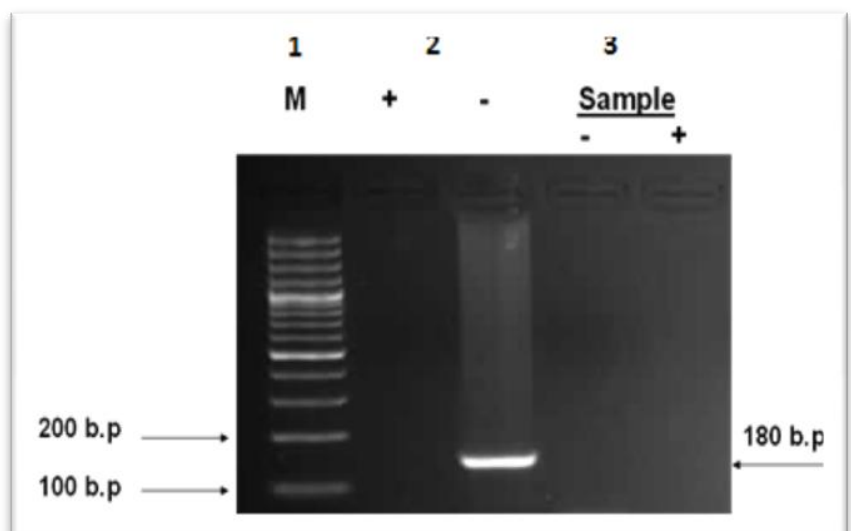

Fig. 5: PCR amplification picture of HCV RNA (+) and (-) strands in the presence of supernatant of the bacterial strain P. piscicida. Lane 1: contains the molecular weight marker (M) 100bp ladder, lane 2: control, and lane 3: effect of the supernatant of the bacterial strain P. piscicida $(100 \mu \mathrm{g} / \mathrm{ml}$.) on HCV RNA $(+)$ and $(-)$ strand after 8 days of treatment.

\section{Antioxidant activity}

As shown in table 10, the sample has a significant antioxidant activity compared with ascorbic acid as control. The percent of inhibition were $(4.92,24.36,32.51,35.59$ and $39.13 \%$ ) respectively for the sample and $(10.64,28.86,39.76,48.56$ and $60.32 \%$ ) respectively for ascorbic acid, which proves that there is linear relationship between antioxidant capacity and phenolic content. This result was almost in accordance with that reported by Nurul et al. (2011). The bacteria belonging to genera Pseudoalteromonas were reported for their antioxidant activity (Velho-Pereira et al., 2015).

Table 10: DPPH stable free radical scavenging activity of sample $\%$.

\begin{tabular}{|c|c|c|}
\hline Sample concentration $(\mathrm{mg} / \mathrm{ml})$ & $\%$ Inhibition & Ascorbic acid \\
\hline 6.25 & 4.92 & 10.64 \\
\hline 12.5 & 24.36 & 28.86 \\
\hline 25 & 32.51 & 36.76 \\
\hline 50 & 35.59 & 48.56 \\
\hline 100 & 39.13 & 60.32 \\
\hline
\end{tabular}

\section{Chemical characterization of the benzene extract}

Chemical composition of the benzene extract was determined using GC-MS. The chemical constituents in the crude extract are shown in Table 11.

Results indicated that the major components in this extract are Di-n-octyl phthalate representing $22.05 \%$ afforded $(0.20 \mathrm{~g} / \mathrm{l})$ of the extract, Benzene,1-butyheptyl $(8.4 \%)$ afforded
$(0.0848 \mathrm{~g} / \mathrm{l})$ of the extract and Benzene, (1-pentyloctyl) (8.2 $\%)$ afforded $(0.0828 \mathrm{~g} / \mathrm{l})$ of the extract with molecular weight 390, 232 and 260 respectively. Mass spectrum of the most active compound (Di-n-octyl phthalate) is illustrated in Figure 6a. Chemical characterization including UV and IR analysis were carried out as illustrated in Figure 6 b,c. IR spectra of the active compound showed peaks at $3448,300.15 \mathrm{~cm}^{-1}$ (O-H stretching), $2135.67 \mathrm{~cm}^{-1}$ (C-H alkane), 1714, $1640.38 \mathrm{~cm}^{-1}$ (C=O stretching), 1361.90, $1422.08 \mathrm{~cm}^{-1} \quad\left(\mathrm{C}=\mathrm{C}\right.$ aromatic), $1221, .281092 .22 \mathrm{~cm}^{-1}$ (Aromatic C-O).

Table 11: Chemical composition of the three major compounds of the benzene crude extract obtained from P.piscicida and fractionated using GC/MS analysis.

\begin{tabular}{|c|c|c|c|c|c|}
\hline Compound & 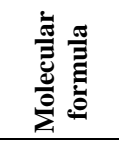 & 氞 & 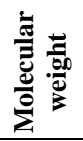 & $\frac{2}{4}$ & 莺 \\
\hline Benzene, (1-butylheptyl) & $\mathrm{C}_{17} \mathrm{H}_{28}$ & 13.769 & 232 & 8.4 & 96 \\
\hline Benzene, (1-pentyloctyl) & $\mathrm{C}_{19} \mathrm{H}_{32}$ & 15.205 & 260 & 8.2 & 93 \\
\hline Di-n-octyl phthalate & $\mathrm{C}_{24} \mathrm{H}_{38} \mathrm{O}_{4}$ & 25.717 & 390 & 22.05 & 97 \\
\hline
\end{tabular}
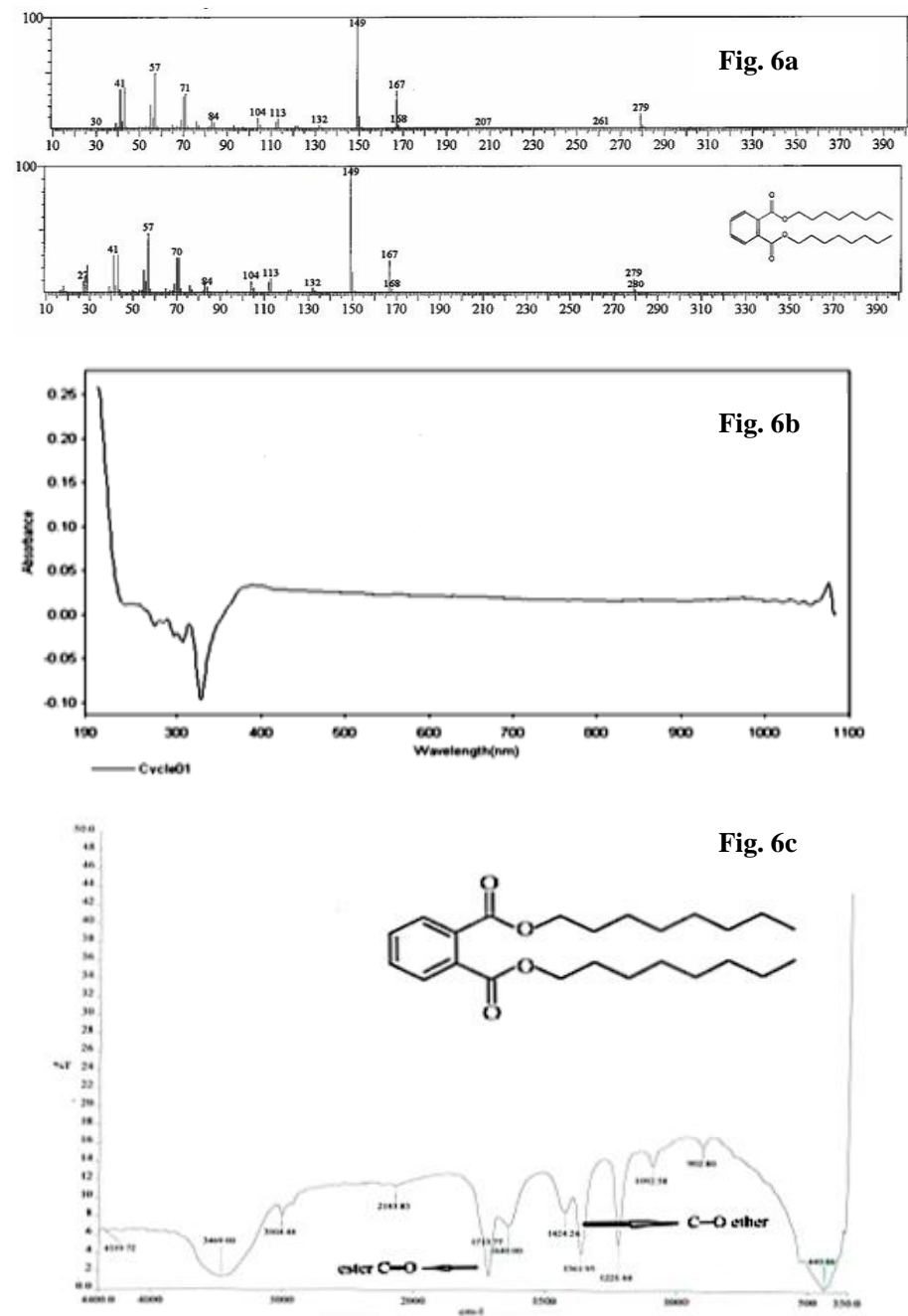

Fig. 6: Characterization of the purified Di-n-octyl phthalate a) Mass spectrum using GC-MS, b) UV spectrum and c) IR spectrum. 
The major chemical component Di-n-octyl phthalate was proven to have pharmaceutical uses as was reported by Kim et al. (2004) who stated that phthalates which include butyl benzyl phthalate (BBP), di(n-butyl) phthalate (DBP), and di (2 ethylhexyl) phthalate (DEHP) had been demonstrated anticancer activity. Moreover, phenolic compounds exhibits antimicrobial activity (Patra and Baek, 2016; Rodríguez-Pérez et al., 2016; Marín et al., 2016; Tuberoso et al., 2016) and may reduce the risk of cardiovascular disease and stroke In these ways, phenolic compounds may also confer protection against chronic diseases such as atherosclerosis and assist in the management of menopausal symptoms. Thus, phenolic compounds have been referred to as semi essential food components.

\section{CONCLUSIONS}

Marine environment is an exploding source of microorganisms with potentiality of their bioactive compounds. The aim of the present study was to search for marine bacteria as an ecofriendly source of bioactive compounds with various uses. The findings of the present approach suggested that the bioactive compounds produced by marine $P$. piscicida could be used as antibiotics, and might have future biomedical applications as anticancer, antiviral and antioxidant agents. Complete identification of the extracted bioactive compounds will be tracked in the future study.

Financial support and sponsorship: Nil.

Conflict of Interests: There are no conflicts of interest.

\section{REFERENCES}

Aassila H, Bourguet- kondracki ML, Rifai S, Fassouane A et al. Identification of Harman as the antibiotic compound produced by a tunicate associated bacterium. Mar Biol, 2003; 5: 163-166.

Abd-Elnaby H, Abo-Elela G, Abdel-Raouf U. Antibacterial and anticancer activity of marine Streptomyces parvus: Optimization and application. Biotechnol Equip, 2016; 30(1): 180-191.

Abou-Elela GM, El-Sersy N, Wefky SH. Statistical optimization of cold adapted $\alpha$-amylase production by free and immobilized cells of Nocardiopsisaegyptia. J Appl Sci Res, 2009; 5: 286292.

AOCS (1990). In: Official Methods and recommended practices of the American Oil Chemists Society ( $4^{\text {th }}$ ed.). Champaign: American Oil Chemists Society.

Bérdy J. Bioactive microbial metabolites. J Antibiot, 2005; 58:

$1-26$.

Bhatnagar I, Kim S. Marine antitumor drugs: Status, shortfalls and strategies. Mar Drugs, 2010; 9: 1391-1402.

Blunt J, Copp W, Keyzers BR, Munro RA, Prinsep MH. Marine natural products. Nat. Prod. Rep, 2015; 32: 116-211.

Bowman JP. Bioactive compound synthetic capacity and ecological significance of marine bacterial genus Pseudoalteromonas. Mar Drugs, 2007; 5: 220-241.

Cohran WG, Snedecor GW. 1989. Statistical methods. P.466.low astate UniversityPress ,Ames, Lowa 50041. Darah I, Sumathi G, Jain K, Lim SH. Tannase enzyme production by entrapped cells of Aspergillus niger FETL FT3 in submerged culture system. Bioprocess Biosystems Eng, 2011; 34: 795-801.
Donlan RM, Costerton JW. Biofilms: survival mechanisms of clinically relevant microorganisms. Clin Microbiol Rev, 2002; 15: 167193.

Eduardo J, Gudiña, Elisabete C, Fernandes, Rodrigues A, José A, Teixeira and Rodrigues R. Biosurfactant production by Bacillus subtilis using corn steep liquor as culture medium. Front Microbiol, 2015; 6: 1-7.

El-Awady MK, Ismail SM, El-Sagheer M, Sabour YA et al. Assay for Hepatitis $\mathrm{C}$ virus in peripheral blood mononuclear cells enhances sensitivity of diagnosis and monitoring of $\mathrm{HCV}$ associated Hepatitis. Int J Clin Chem, 1996; 283(1-2):1-14.

El-Hawash SA; Abdel Wahab AE, El-Demellawy MA. Cyanoacetic acid hydrazones of 3-(and 4-)acetylpyridine and some derived ring systems as potential antitumor and anti-HCV agents. Arch Pharm, 2006; 339(1): 14-23.

El-Masry MH, Khalil, AI Hassouna MS, Ibrahim HAH. In situ and in vitro suppressive effect of agricultural composts and their water extracts on some phytopathogenic fungi. World J Microbiol Biotechnol, 2002; 18: 551-558.

Elnahas M., Darwish M, Ali A, Amin M. Characterization of an exopolysaccharide-producing marine bacterium, isolate Pseudoalteromonas sp. AM. Afr J Microbiol Res, 2011; 5(22):3823-3831. 5(22):3823-3831.

El-Sersy NA. Bioremediation of methylene blue by Bacillus thuringiensis4 G1: Application of statistical designs and surface plots for optimization. Biotechnol, 2007; 6: 34-39.

El-Sharouny EE, El-Toukhy NMK, El-Sersy NA, et al. Optimization and purification of mannanase produced by an alkaliphilicthermotolerant Bacillus cereus N1 isolated from Bani Salama Lake in Wadi El-Natron. Biotechnol Equip, 2015; 29(2):315323.

$\mathrm{Hu}$ C, Kitts DD. Studies on the antioxidant activity of Echinacea root extract. J Agric Food Chem, 2000; 48: 1466-1472.

Ivanova $\mathrm{EP}$, Chipeva $\mathrm{V}$, Ivanova $\mathrm{I}$, Douoset $\mathrm{X}$ et al. Encapsulation of lactic acid bacteria in calcium alginate beads for bacteriocin production. J Cult Coll, 2000-2002; 3: 53- 58.

Ivanova EP, Nivolau DV, Yumoto N, Taguchi T et al. Impact of conditions of culturing and adsorption on antimicrobial activity of marine bacteria Mar Biol, 1998; 130: 545-551.

Kaoutar B, Baibai T, Mountassif D, Retmane A, Soukri A. Antibacterial activities of the crude ethanol extracts of medicinal plants against Listeria monocyte genes and some other pathogenic strains. Afr J Biotechnol. 2010; 27: 4251-4258.

Kim IY, Han SY, Moon A. Phthalates inhibit tamoxifeninduced apoptosis in MCF-7 human breast cancer cells J Toxicol Environ Health, 2004; 67: 2324.

Kim WJ, Kim YO, Kim JH, Nam B，Kim D，An CM，Lee JS, Kim PS, Lee HM, Oh J, Lee JS. Liquid Chromatography-Mass Spectrometry-based rapid secondary-metabolite profiling of marine Pseudoalteromonas sp. M2. Mar. Drugs, 2016; 14(2): 24. Leekha S, Terrell CL, Edson RS. General Principles of antimicrobial therapy. Mayo Clin Proc, 2011; 86(2): 156-167.

Llamas I, Mata JA, Tallon R, Bressollier P, Urdaci MC, Quesada E, Béjar V. Characterization of the exopolysaccharide Produced by Salipiger mucosus A3T, a Halophilic species belonging to the alphaproteobacteria, isolated on the Spanish Mediterranean Seaboard. Mar Drugs, 2010; 8(8): 2240-2251.

Lunestad BT, GoksQy. Reduction in the antibacterial effect of oxytetracycline in sea water by complex formation with magnesium and calcium. Dis Aquat Org, 1990; 9: 67-72.

Marín I, Sayas-Barberá S, Viuda-Marto M, Navarro C, Sendra E. Chemical composition, antioxidant and antimicrobial activity of essential oils from organic fennel, parsley, and lavender from spain. Foods, 2016; 5: 1-10.

Mikhailov VV, Romanenko LA, Ivanova EP. 2002. The genus Alteromonas and related Proteobacteria. In: Dworkin M, Falkow S, Rosenberg E, Schleifer KH, Stackebrandt E, eds.The Prokaryotes.3rd.Springer; New York, NY, USA 597-645. Navarri, Jégou C, Meslet-Cladière L, Brillet B, Barbier G, Burgaud G, 
Fleury Y. Deep subseafloor fungi as an untapped reservoir of amphipathic antimicrobial compounds. Mar Drugs, 2016; 14: 50.

Newman DJ, Cragg GM. Natural products as sources of new drugs over the last 25 years. J Nat Prod, 2007; 70: 461-47.

Noble KK, Laxmi M, Harisree PN, Sarita GP. Materials. Melanins with antibiofilm and anticancer activities from marine pseudoalteromonas lipolytica BTCZ 28. Boil. Biotechnol Biosensors, 2016; 297-299.

Nurul AZ, Darah I, Shaida FS, Nor AS. Assessment of antioxidant activity, total phenolic content and invitro toxicity of Malaysian red seaweed, Acanthophoraspicifera. J Chem Pharm Res, 2011; 3(3): 182-191.

Patra JK, Baek K. Antibacterial activity and action mechanism of the essential oil from Enteromorpha linza L. against foodborne pathogenic bacteria. Molecules, 2016; 21: 1-11.

Plackett RL, Burman JP. The design of optimum multifactorial of experiments. Biomet, 1946; 33: 305-325.

Pursell L, Samuelsen OB, Smith B. Reduction in the in vitro activity of fluemequine against Aeromonas salmonicida in the presence of concentrations of $\mathrm{Mg}^{2+}$ and $\mathrm{Ca}^{2+}$ ions found in sea water Aquaculture, 1995; 135: 245-255.

Rodríguez-Pérez C, Quirantes-Piné R, Uberos J, JiménezSánchez C, Peña C, Segura-Carretero A. Antibacterial activity of isolated phenolic compounds from cranberry (Vaccinium macrocarpon) against Escherichia coli. Food Funct, 2016; 7: 1564-73.

Saraniya A, Jeevaratnam K. Optimization of nutritional and non - nutritional factors involved for production of antimicrobial compounds from Lactobacillus pentosus SJ65 using response surface methodology. Braz J Microbiol, 2014; 45(1): 81-88.

Secun J B, , Santoyo AH, , Padilla VM, , Alcántara RL. Antimicrobial protein of the marine bacterium Pseudoalteromonas sp. and its proteolytic property. J Pharm Res, 2015; 9(7): 457-462

Shabbiri K, Adnan A, Jamil S, Ahmad W et al. Medium optimization of protease production by Brevibacteriuminens DSM 20158, using statistical approach. Braz J Microbiol, 2012; 43(3): 1051-61.

Sharma D, Manhas, RK. Applications of Plackett-Burman experimental design and Box and Wilson design to improve broad spectrum antimicrobial compound. Indian J Biotechnol, 2013; 12: 386394.

Tuberoso I, Jerkovi M. Maldini GJ, Serreli. Phenolic compounds, antioxidant activity, and other characteristics of extra virgin olive oils from Italian Autochthonous Varieties Tonda di Villacidro , Tonda di Cagliari, Semidana , and Bosana. J. Chem, 2016: 1-7.

Urvish C, Gupte A. Optimization of media components for laccase production by litter dwelling fungal isolate Fusarium incarnatum LD-3 J. Basic Microbiol, 2010; 50: 43-51.

VanderMolen K M, Huzefa AR, Tamam El-Elimat, Oberlies $\mathrm{NH}$. Evaluation of culture media for the production of secondary metabolites in a natural products screening program.AMB Express, 2013; 3: 71 .

Velho-Pereira S, Parvatkar P, Furtado IJ. Evaluation of antioxidant producing potential of halophilic bacterial bionts from marine invertebrates. Indian J Pharm Sci, 2015; 77: 183-189.
Vimala R. Marine organisms: A potential source of natural antifouling metabolites. Int. J.Chem.Tech. Res, 2016; 9: 208-217.

Vynne NG, Gram L. Bioactivity, Chemical Profiling, and 16S rRNA-Based Phylogeny of Pseudoalteromonas strains collected on a global research cruise. Mar Biotechnol, 2011; 1062-1073.

Waters AL, Hill RT, Place AR, Hamann MT. The expanding role of marine microbes in pharmaceutical development. Curr Opin Biotechnol, 2010; 21: 780-786.

Wang Y, Nakajima A, Hosokawa K, Soliev AB, Osaka I, Enomoto R. Cytotoxic prodigiosin family pigments from Pseudoalteromonas sp. 1020R isolated from the Pacific coast of Japan . Biosci Biotechnol Biochem, 2012; 76: 1229-1232.

Wefky SH, Abou-Elela GM, El-Bestawy E. Optimization of fermentation conditions for bioactive compounds production by marine bacterium Enterococcus faecium. J Applied Sci Res, 2009; 5(10): 1445-54

Xiong ZQ, Zhang ZP, Li JH, Wei, SJ et al. Characterization of Streptomyces padanus JAU 4234, a producer of actinomycin X2, fungichromin, and a new polyene macrolide antibiotic. Appl Environ Microbiol, 2012; 78: 589-592.

Yu X, Hallett SG, Sheppard J, Wasrom AK. Application of the Plackett-Burman experimental design to evaluate nutritional requirements for the production of Colletotrichum coccodes spores Appl Microbiol Biotechnol, 1997; 47: 301-305.

Zeinab A K, Aly MS, Faiza A, Fatma E M. The PlackettBurman design to evaluate significant media components for antimicrobial production of Lactobacillus rhamnosus. Int J Curr Microbiol App Sci, 2015; 4: 1082-1096

Zheng L, Yan X, Han X, Chen H, Lin W, Lee F, Wang X. Identification of norharman as the cytotoxic compound produced by the sponge (Hymeniacidon perleve)-associated marine bacterium Pseudoalteromonas piscicida and its apoptotic effect on cancer cells. Biotechnol Appl Biochem, 2006; 44: 135-142.

Zhou W, Zeng C, Liu R, Chen J, Li R, Wang X, Bai WE, Liu $\mathrm{X}$, Xiang T, Zhang L, Wan Y. Antiviral activity and specific modes of action of bacterial prodigiosin against Bombyx mori nucleopolyhedro virus in vitro. Appl Microbiol Biotechnol, 2016; 100: 3979-3988.

\section{How to cite this article:}

Mostafa SW, El-Sersy NA, Abdelwahab AE, Ali MAR. Statistical optimization and valuable applications of bioactive compounds produced by marine Pseudoalteromonas piscicida. J App Pharm Sci, 2017; 7 (10): 084-093. 